\title{
Comparative performance of lab tests and blood testing device to monitor glucose, total cholesterol and triacylglycerol in type 2 diabetic patients
}

\author{
Arnaldo Zubioli', Marcia Regina Batista ${ }^{2}$, Talitha Fernandes Stefanello², Marcia Aparecida \\ Carrara $^{1}$, Roberto Barbosa Bazotte ${ }^{1, *}$ \\ ${ }^{1}$ Department of Pharmacy and Pharmacology, State University of Maringá, ${ }^{2}$ Department of Clinical Analysis, \\ State University of Maringá
}

\begin{abstract}
The performance of lab tests (LT) and blood testing devices (BTD) to monitor glycemia vs. glycated hemoglobin A1c (A1c) were compared. In addition, the performance of blood glucose, total cholesterol (TC) and triacylglycerol measured by LT and BDT were compared. All parameters were measured based on the same blood samples from overnight fasted type 2 diabetic patients (T2DP). Linear regression analysis was used for all comparisons. The results showed that A1c correlated better with LT-glucose $(\mathrm{r}=0.58)$ than BTD-glucose $(\mathrm{r}=0.42)$. Moreover, LT vs. BTD showed $\mathrm{r}$ values of $0.90,0.82$ and 0.92 for glucose, TC and triacylglycerol, respectively. It was concluded that the performance of LT-glucose was better than BDT-glucose. Moreover, since triacylycerol and TC measured by BTD correlated better with LT compared to BDT-glucose $v s$. LT-glucose, the inclusion of BTD-TC and BTD-triacylglycerol for detecting and monitoring hyperlipidemia in T2DP should be considered.
\end{abstract}

Uniterms: Laboratory tests. Glycated hemoglobin. Glycemia. Total cholesterol. Triacylglycerol. Type 2 diabetes.

Comparou-se a performance de avaliação da glicemia através de dosagens laboratoriais (DL) ou dispositivo para teste de sangue capilar (DTSC) vs. hemoglobina glicada A1c (A1c). Comparou-se ainda a performance de avaliação da glicemia, colesterol total (CT) e triacilglicerol (DL vs. DTSC). Avaliou-se estes parametros a partir das mesmas amostras de sangue coletadas em pacientes diabéticos tipo 2 (PDT2) em jejum noturno, sendo as comparações realizadas através de análise de regressão linear. A A1c correlacionou-se melhor com a glicemia-DL $(r=0,58)$ em relação a glicemia-DTSC $(\mathrm{r}=0,42)$. Comparou-se DL vs. DTSC obtendo se $\mathrm{r}=0,90,0,82$ e 0,92 para glicemia, CT e triacilglicerol, respectivamente. Concluiu-se que houve melhor performance da glicose-DL em relação a glicose-DTSC. Além disso, considerando que o triacilglicerol e TC avaliado através de DTSC correlaciona-se melhor com DL em comparação a DTSC-glicose vs. DL-glicose, a inclusão de DTSC-TC e DTSC-triacilglicerol visando detectar e monitorar hyperlipidemia in PDT2 deve ser considerada.

Unitermos: Exames laboratoriais. Hemoglobina glicada. Glicemia. Colesterol total. Triacilglicerol. Diabetes tipo 2.

\section{INTRODUCTION}

Glycemic control is fundamental in the management of type 2 diabetes. The United Kingdom Prospective Diabetes Study (UKPDS), a prospective, randomized, controlled trial of intensive versus standard glycemic control in

\footnotetext{
*Correspondence: R. B. Bazotte. Universidade Estadual de Maringá, Departamento de Farmacia e Farmacologia. Avenida Colombo, 5790 -, 87020-900 - Maringá - PR, Brasil. E-mail: rbbazotte@uem.br
}

type 2 diabetic patients, showed definitively that improved glycemic control is associated with significantly decreased rates of diabetic complications (UK Prospective diabetes study group (1998).

Moreover, epidemiological analyses of the UKPDS demonstrated a curvilinear relationship between glycated hemoglobin A1c and diabetic complications, suggesting that the majority of complications could be prevented by the implementation of good glycemic control (Stratton et 
al., 2000). This study also suggested that further lowering of glycated hemoglobin A1c from 7 to $6 \%$ was associated with significant reduction of diabetic complications. In agreement, the American Diabetes Association suggested glycated hemoglobin A1c of less than $7 \%$ to prevent chronic complications (American Diabetes Association, 2010).

However, in spite the fact that glycated hemoglobin A1c is considered the cornerstone of clinical management of diabetes, (American Diabetes Association, 2010) fasting glycemia is the most widely used lab test to evaluate the glycemic status of people with diabetes (Al-Lawati, Al-Lawati, 2007; Correr et al., 2009; Silva et al., 2004).

Furthermore, in recent years a clear tendency for evaluating blood glucose, total cholesterol and triacylglycerol with blood testing devices has emerged (Laguna et al., 2009; Nathan et al., 2008; Cassani et al., 2009; Pongwecharak, Treeranurat, 2010). However, the performance of these methods in comparison with classical lab tests is not yet well established.

In the present investigation, the performance of blood glucose measurements from lab tests and blood testing devices for glycated hemoglobin A1c levels was compared. Moreover, the performance of lab tests and blood testing devices was also compared for glucose, total cholesterol and triacylglycerol measurements.

\section{PATIENTS AND METHODS}

Written consent to participate in this investigation was obtained from each patient and the study was approved by the Ethics Committee of the State University of Maringá (COPEP - CAAE 0133-06).

Exclusion criteria were pregnancy, gestational diabetes, type 1 diabetes and other specific types of diabetes. Eligibility criteria were: age over 30 years, confirmed diagnosis of type 2 diabetes and use of at least one prescribed anti-diabetic drug.

The patients, recruited from a pharmacy school, were interviewed and information on medical history, socio-demographic characteristics, pharmacotherapeutic profile and lifestyle were collected. After the interview, blood pressure (BP) and body mass index (BMI) were evaluated. BP ( $\mathrm{mmHg})$ was measured as described elsewhere (Ferri et al., 2006).

Immediately after the interview the patients received instructions for blood collection at a laboratory accredited by the Brazilian Society of Clinical Analysis.

Venous blood was collected from overnight fasted patients for analysis of glucose, total cholesterol and triacylglycerol by a blood testing device (BTD) and lab tests (LT). In addition, glycated hemoglobin A1c was measured. All analyses were done from the same blood sample.

Immediately after blood collection, part of the fresh blood was immediately used to measure glycated hemoglobin A1c (Metus et al., 1999), glucose, total cholesterol and triacylglycerol by BTD (Accutrend GCT $^{\circledR}$ - Roche Company). The normal values of glycated hemoglobin A1c, glucose, total cholesterol and triacylglycerol were $<7 \%, 70-130 \mathrm{mg} / \mathrm{dL},<200 \mathrm{mg} / \mathrm{dL}$ and $<200 \mathrm{mg} / \mathrm{dL}$, respectively.

Moreover, part of the blood was transferred to a tube containing sodium fluoride/EDTA, which was immediately centrifuged and the plasma separated to measure glucose (Bergmeyer, Bernt, 1974), total cholesterol (Allain et al., 1974) and triacylglycerol (Bucolo, David, 1973) by LT. The normal values of blood glucose, total cholesterol and triacylglycerol were $<100 \mathrm{mg} / \mathrm{dL},<200 \mathrm{mg} / \mathrm{dL}$, and $<150 \mathrm{mg} / \mathrm{dL}$, respectively. These values were based in the position statement of the Clinical Practice Recommendation of the American Diabetes Association (2010).

Linear regression analysis using GraphPad Prism (version 5) was done to investigate the relationship between glycated hemoglobin A1c vs. glucose (LT), A1c vs. glucose (BTD), glucose (LT vs. BTD), total cholesterol (LT vs. BTD) and triacylglycerol (LT vs. BTD).

Some results were expressed as percentage (\%) and others as mean \pm standard deviation (SD).

\section{RESULTS}

A total of 32 volunteers, 16(50\%) men and 16(50\%) women, were assessed. The values for all biochemical parameters did not differ between men and women (data not shown).

Among these patients, whose mean age was $57.8 \pm$ 7.3 years ranging from 48 to 74 years, the time of diagnosis was $12.0 \pm 9.0$ years, ranging from 1 to 37 years.

Most patients had one or more comorbidities associated with diabetes, with a prevalence of hypertension (93.8\%) and overweight or obesity (68.8\%).

The value of glycated hemoglobin A1c, glucose (LT), glucose (BTD), total cholesterol (LT), total cholesterol (BTD), triacylglycerol (LT) and triacylglycerol (BTD) were $9.2 \pm 2.3 \%, 176.5 \pm 56.3 \mathrm{mg} / \mathrm{dL}, 129.2 \pm 44.2 \mathrm{mg} / \mathrm{dL}$, $181.1 \pm 36.9 \mathrm{mg} / \mathrm{dL}, 182.2 \pm 21.8 \mathrm{mg} / \mathrm{dL}, 147.5 \pm 88.0 \mathrm{mg} / \mathrm{dL}$ and $194.7 \pm 90.0 \mathrm{mg} / \mathrm{dL}$, respectively.

The number $(\%)$ of patients with altered values for glycated hemoglobin A1c, glucose (LT), glucose (BTD), total cholesterol (LT), total cholesterol (BTD), triacyl- 
glycerol (LT) and triacylglycerol (BTD) were 25 (78.1\%), 24 (75.0\%), 14 (43.8\%), 9 (32\%), 4 (14.3\%), 10 (33.3\%) and 13 (41.9\%), respectively (Table I).

As can be seen in Figure 1A and 1B, glycated hemoglobin A1c correlated better with glucose measu- red by LT $(r=0.58)$ than BTD $(r=0.42)$. On the other hand, the comparison of LT and BTD show $r$ values of $0.90,0.82,0.92$ and glucose (Figure 2A), total cholesterol (Figure 2B) and triacylglycerol (Figure 2C), respectively.

TABLE I - Individual and mean (M) \pm standard deviation (SD) of glycated hemoglobin A1c (A1c), blood, glucose (GLU), total cholesterol (TC) and triacylglycerol (TG). GLU, TC and TG were measured by Lab test (LT) and blood testing device (BTD). A1c was expressed as $\%$ and all other parameters were expressed as $\mathrm{mg} / \mathrm{dL}$. Blood was collected from overnight fasted type 2 diabetic patients. nd: not determined

\begin{tabular}{|c|c|c|c|c|c|c|c|}
\hline Patient & $\mathrm{A} 1 \mathrm{c}$ & GLU - LT & GLU-BTD & TC $-\mathbf{L T}$ & TC-BTD & TG - LT & TG - BTD \\
\hline 1 & 8.4 & 156 & 88 & 166 & 150 & 192 & 229 \\
\hline 2 & 8.2 & 192 & 158 & 237 & 193 & 224 & 267 \\
\hline 3 & 9.9 & 188 & 117 & 107 & 167 & 88 & 143 \\
\hline 4 & 9.5 & 180 & 98 & 172 & 193 & 322 & 246 \\
\hline 5 & 10.3 & 169 & 103 & 170 & 174 & 93 & 146 \\
\hline 6 & 12.8 & 229 & 158 & 202 & 196 & 202 & 255 \\
\hline 7 & 7.5 & 168 & 144 & 202 & 190 & 130 & 192 \\
\hline 8 & 9.6 & 264 & 196 & 172 & 180 & 206 & 292 \\
\hline 9 & 9.6 & 196 & 169 & 142 & 169 & 192 & 193 \\
\hline 10 & 11.6 & 252 & 179 & 210 & 200 & 95 & 138 \\
\hline 11 & 12.4 & 266 & 216 & 218 & 223 & 122 & 177 \\
\hline 12 & 8.7 & 229 & 146 & nd & nd & nd & 101 \\
\hline 13 & 10.6 & 137 & 77 & 182 & 168 & 103 & 156 \\
\hline 14 & 6.4 & 113 & 94 & nd & nd & 127 & 203 \\
\hline 15 & 7.2 & 164 & 110 & nd & nd & 110 & 208 \\
\hline 16 & 6.4 & 103 & 83 & 116 & 168 & 68 & 120 \\
\hline 17 & 7.5 & 121 & 101 & 180 & 171 & 46 & 89 \\
\hline 18 & 6.8 & 92 & 73 & 171 & 165 & 108 & 97 \\
\hline 19 & 11.5 & 219 & 175 & 175 & 180 & 471 & 548 \\
\hline 20 & 11.6 & 301 & 234 & 174 & 169 & 132 & 198 \\
\hline 21 & 7.4 & 126 & 130 & 151 & 157 & 64 & 101 \\
\hline 22 & 9.1 & 212 & 171 & 152 & 165 & 135 & 198 \\
\hline 23 & 9.4 & 184 & 145 & 198 & 175 & 160 & 221 \\
\hline 24 & 7.0 & 173 & 134 & 181 & 175 & 115 & 171 \\
\hline 25 & 6.9 & 148 & 97 & 196 & 185 & 88 & 138 \\
\hline 26 & 8.7 & 51 & 53 & 202 & 200 & 37 & 88 \\
\hline 27 & 7.2 & 156 & 107 & 207 & 199 & 119 & 183 \\
\hline 28 & 14.1 & 173 & 87 & 286 & 250 & nd & nd \\
\hline 29 & 13.9 & 155 & 114 & 132 & 160 & 91 & 134 \\
\hline 30 & 6.8 & 126 & 91 & nd & nd & 143 & 213 \\
\hline 31 & 12.2 & 258 & 176 & 215 & 213 & 192 & 269 \\
\hline 32 & 6.3 & 148 & 111 & 157 & 168 & 250 & 322 \\
\hline $\mathbf{M}$ & 9.2 & 176.5 & 129.2 & 181.1 & 182.2 & 147.5 & 194.7 \\
\hline SD & 2.3 & 56.3 & 44.2 & 36.9 & 21.8 & 88.0 & 92.0 \\
\hline
\end{tabular}


1A. HbA1c vs. Glycemia (Lab test)

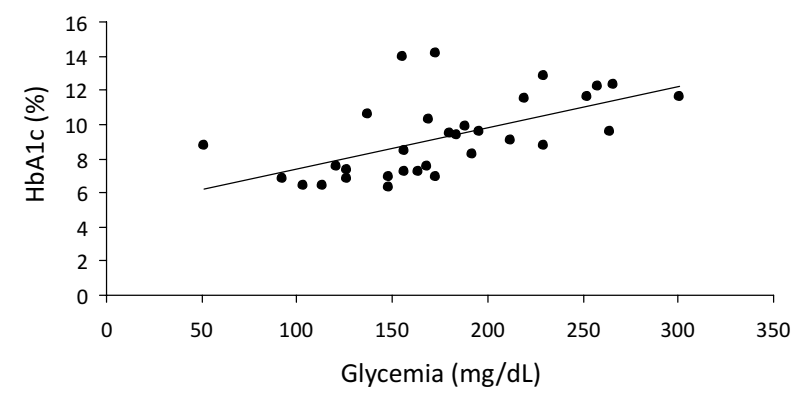

1B. HbA1c vs. Glycemia (BTD)

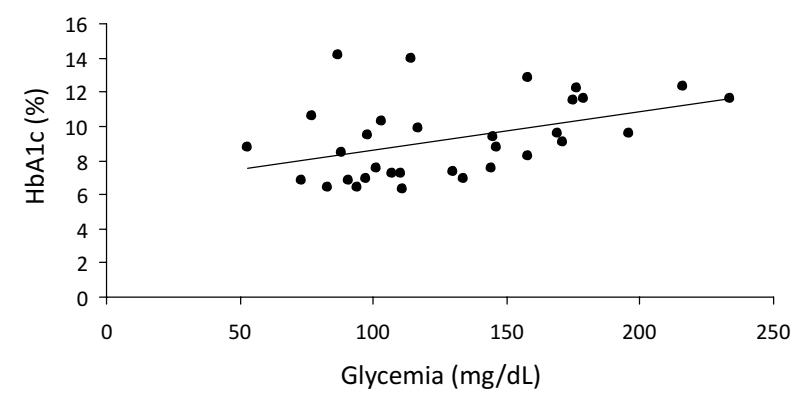

FIGURE 1 - Relationship between glycated hemoglobin A1c (HbAlc) and fasting glycemia measured by Lab test $(1 \mathrm{~A})$ and blood testing device (BTD) (1B). Number of patients: 32 .

\section{DISCUSSION}

Type 2 diabetes is now a major public health problem in Brazil. The estimated number of 5.2 million sufferers in 2000 is expected to double by the year 2030 (Wild et al., 2004). However, glycemic control is lower than 50\% (Gomes et al., 2006; Assunção, Santos, Valle, 2005), which inevitably contributes to the increasing occurrence of chronic complications in type 2 diabetic patients.

Furthermore, type 2 diabetes is normally asymptomatic, but if the disease is not adequately treated a range of chronic complications can result in reduced quality of life and premature death (Assunção, Santos, Valle, 2005).

Therefore, monitoring the treatment of type 2 diabetes has important implications for individual health and public health policy and for this purpose fasting glycemia is the most commonly used exam (Silva, Bazotte, 2010; Pimentel et al., 2010). Moreover, considering the high risk of cardiovascular disease, the control of blood lipid profile must be considered (Colagiuri, 2010).

Our results showed that the majority of the patients did not exhibit suitable control of glycemia and lipid profile (Table I). These results are in line with the findings of several other studies, in which the majority of type 2 diabetic patients exhibited poor blood glucose and lipid
2A. Glucose (GLU)

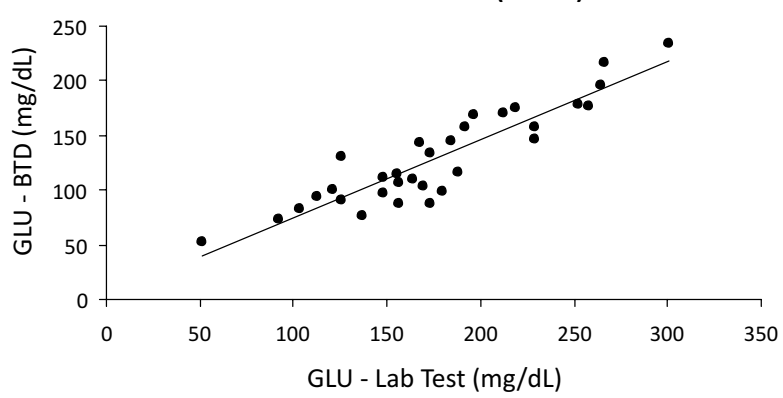

2B. Total Cholesterol (TC)

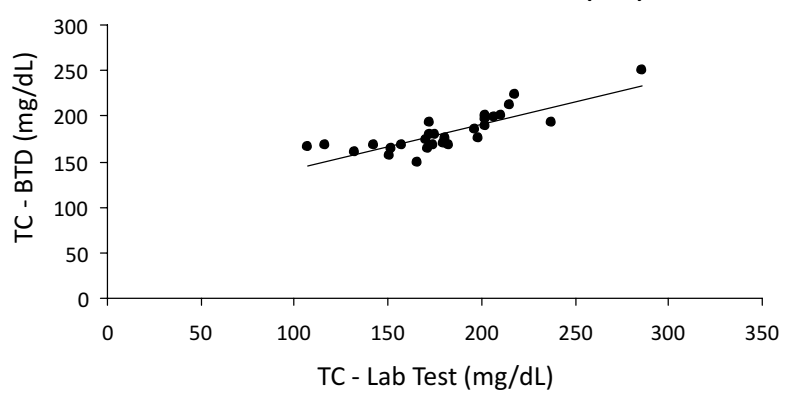

2C. Triacylglycerol (TG)

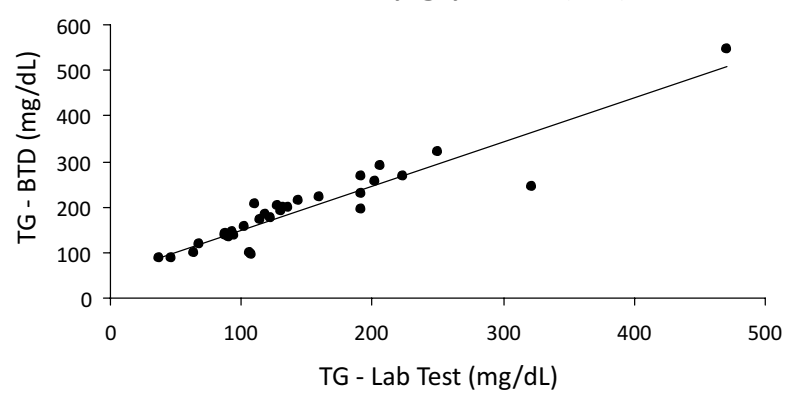

FIGURE 2 - Relationship between lab test and blood testing device (BTD) for glycemia (2A), total cholesterol (2B) and triacylglycerol (2C). Number of patients: 32 .

control (Kemp et al., 2005; Saydah, Fradkin, Cowie, 2004; McFarlane et al., 2002; Grant, Buse, Meigs, 2005; Silva, Bazotte, 2010).

Linear regression analysis to investigate the relationship between glycated hemoglobin A1c vs. fasting glycemia (LT and BTD) revealed that glycated hemoglobin A1c correlated better with LT than with BTD (Figure 1A, B). Furthermore, in the case of patients 1,4,13,26 and 28 (Table I), fasting glycemia obtained by BTD, i.e., $\leq$ $100 \mathrm{mg} / \mathrm{dL}$, could yield misleading information of good glycemic control since results contrasted with the elevated values of glycated hemoglobin A1c. For LT, this problem is limited to patient 26 (Table I). Therefore, in spite of the fact that glycemia measured by BTD has become faster and more accurate over the past 3 decades and now allows 
for better glycemic control by diabetics than in the past, this test is no substitute for fasting glycemia values obtained by lab tests.

There is consensus on continuous monitoring of lipid profile in type 2 diabetes. This question acquires greater relevance considering that diabetes is a significant cardiovascular risk and given that blood lipid targets are not attained by the majority of type 2 diabetic patients (Gomes et al., 2006; Grant, Buse, Meigs, 2005; Silva, Bazotte, 2010). In this context, our results showed that, in spite of the fact that BTD for measuring total cholesterol and triacylglycerol were introduced into clinical practice later than glycemia, they show good correlation with laboratory results. In the specific case of triacylglycerol, the $r$ value $(r=0.92)$ for comparison of BTD vs. LT was higher than that obtained for glucose $(r=0.90)$.

\section{CONCLUSION}

Congruent with the well-established role of BTD in the detection and self-monitoring of glycemia, the Brazilian Government approved RDC 44/ANVISA (Resolução da Diretoria Colegiada, 2009) in which capillary glycemia was established as a pharmaceutical service care for diabetes screening and glucose monitoring. However, considering that glycated hemoglobin A1c correlated better with LT than BTD, device tests are no substitute for the fasting glycemia values obtained by lab tests. Finally, since BTDTC and BTD-triacylglycerol showed good correlation with LT, the inclusion of BTD-TC and BTD-triacylglycerol in the detection and monitoring of hyperlipidemia in T2DP should be considered.

Finally, any analysis of the results must consider the limited number of patients investigated, i.e., 32 volunteers. However, this limitation was overcome, partly at least, by the fact that all biochemical parameters were evaluated based on the same blood sample. This experimental approach, in which each patient served as their own control, rules out the interference of several factors such as age, duration of diabetes, gender, BMI and variability owing to blood collection on different days. However, future studies involving a higher number of patients are necessary to confirm the conclusions of this study.

\section{ACKNOWLEDGMENTS}

We are grateful to Carlos Eduardo de Oliveira and Solidalva Caruso de Oliveira for their technical assistance. This research received financial support from the Brazilian government (CNPq, CAPES and Araucaria Foundation).

\section{Conflict of Interest}

The authors declare that they have no proprietary, financial, professional, or other personal interest that may influence the conclusions of this study.

\section{Statement}

I hereby confirm that all patients/personal identifiers have been removed or masked to ensure the patient/ person(s) described are not identifiable and cannot be identified through the details of the study.

\section{REFERENCES}

ALLAIN, C.C.; POON, L.S.; CHAN C.S.; RICHMOND, W.; FU, P.C. Enzymatic determination of serum cholesterol. Clin. Chem., v.20, n.4, p.470-475, 1974.

AL-LAWATI, J.A.; AL-LAWATI, A.M. The utility of fasting plasma glucose in predicting glycosylated hemoglobin in type 2 diabetes. Ann. Saudi Med., v.27, n.5, p.347-351, 2007.

AMERICAN DIABETES ASSOCIATION - CLINICAL PRACTICE RECOMMENDATIONS 2010. Diabetes Care, v.33, n.1, p.S1-S61, 2010.

ASSUNÇÃO, M.C.; SANTOS, I.S.; VALLE, N.C. Blood glucose control in diabetes patients seen in primary health care centers. Rev. Saúde Publica, v.39, n.2, p.183-190, 2005.

BERGMEYER, H.U.; BERNT, E. Determination of glucose with glucose-oxidase and peroxidase. In: BERGMEYER, H.U. (Ed.). Methods of enzymatic analysis. New York: Verlag Chemie-Academic Press, 1974. p.1205-1215.

BUCOLO, G.; DAVID, H. Quantitative determination of serum triglycerides by the use of enzymes. Clin. Chem., v.19, n.5, p.476-482, 1973.

CASSANI, R.S.; NOBRE, F.; PAZIN FILHO, A.; SCHMIDT, A. Prevalence of cardiovascular risk factors in a population of Brazilian industry workers. Arq. Bras. Cardiol., v.92, n.1, p.16-22, 2009.

COLAGIURI, S. Diabesity: therapeutic options. Diabetes Obes. Metab., v.12, n.6, p.463-473, 2010. 
CORRER, C.J.; PONTAROLO, R.; SOUZA, R.A.P.; VENSON, R.; MELCHIORS, A.C.; WIENS, A. Effect of a Pharmaceutical Care Program on quality of life and satisfaction with pharmacy services in patients with type 2 diabetes mellitus. Braz. J. Pharm. Sci., v.45, n.4, p.809-817, 2009.

FERRI, L.A.F.; ALVES-DO-PRADO, W.; YAMADA, S.S.; GAZOLA, S.; BATISTA, M.R.; BAZOTTE, R.B. Investigation of the antihypertensive effect of oral crude stevioside in patients with mild essential hypertension. Phytotherapy Res., v.20, n.9, p.732-736, 2006.

GOMES, M.B.; GIANELLA, D.; FARIA, M.; TAMBASCIA, M.; FONSECA, R.M.; RÉA, R.; MACEDO, G.; MODESTO FILHO, J.; SCHMID, H.; BITTENCOURT, A.V.; CAVALCANTI, S.; RASSI, N.; PEDROSA, H.; ATALA DIB, S. Prevalence of Type 2 diabetic patients within the targets of care guidelines in daily clinical practice: a multi-center study in Brazil. Rev. Diabet. Stud., v.3, n.2, p.82-87, 2006.

GRANT, R.W.; BUSE, J.B.; MEIGS, J.B. University Health System Consortium (UHC) Diabetes Benchmarking Project Team. Quality of diabetes care in U.S. academic medical centers: low rates of medical regimen change. Diabetes Care, v.28, n.2, p.337-442, 2005.

KEMP, T.M.; BARR, E.L.; ZIMMET, P.Z.; CAMERON, A.J.; WELBORN, T.A.; COLAGIURI, S.; PHILLIPS, P.; SHAW, J.E. Glucose, lipid, and blood pressure control in Australian adults with type 2 diabetes: the 1999-2000 AusDiab. Diabetes Care, v.28, n.6, p.1490-1492, 2005.

LAGUNA NETO, D.; ROBLES, F.C.; DIAS, F.G.; PIRES, A.C. Analysis of fingerstick capillary glycemia versus alternative site: Results and patients preferences. Arq. Bras. Endocrinol. Metabol., v.53, n.3, p.344-347, 2009.

MCFARLANE, S.I.; JACOBER, S.J.; WINER, N.; KAUR, J.; CASTRO, J.P.; WUI, M.A.; GLIWA, A.; VON GIZYCKI, H.; SOWERS, J.R. Control of cardiovascular risk factors in patients with diabetes and hypertension at urban academic medical centers. Diabetes Care, v.25, n.4, p. 718-723, 2002.
METUS,P.; RUZZANTE, N.; BONVICINI, P.; MENEGHETTI, M.; ZANINOTTO, M.; PLEBANI, M. Immunoturbidimetric assay of glycated hemoglobin. $J$. Clin. Lab. Anal., v.13, n.1, p.5-8, 1999.

NATHAN, D.M.; KUENEN, J.; BORG, R.; ZHENG, H.; SCHOENFELD, D.; HEINE, R.J. A1c-Derived Average Glucose Study Group. Translating the A1C assay into estimated average glucose values. Diabetes Care, v.31, n.8, p.1473-1478, 2008.

PIMENTEL, G.D.; PORTERO-MCLELLAN, K.C.; OLIVEIRA, E.P.; SPADA, A.P.; OSHIIWA, M.; ZEMDEGS, J.C.; BARBALHO, S.M. Long-term nutrition education reduces several risk factors for type 2 diabetes mellitus in Brazilians with impaired glucose tolerance. Nutr. Res., v.30, n.3, p.186-190, 2010.

PONGWECHARAK, J.; TREERANURAT, T. Screening for pre-hypertension and elevated cardiovascular risk factors in a Thai community pharmacy. Pharm. World Sci., 32, n.3, p.329-333, 2010 .

RESOLUÇÃO da Diretoria Colegiada - RDC No 44. August 17, 2009. Available at: <http://www.anvisa. gov.br/divulga/noticias/2009/pdf/180809_rdc_44.pdf $>$. Accessed on: 15 jul. 2010.

SAYDAH, S.H.; FRADKIN, J.; COWIE, C.C. Poor control of risk factors for vascular disease among adults with previously diagnosed diabetes. JAMA. v.291, n.3, p.335342, 2004.

SILVA, G.E.C.; BAZOTTE, R.B. Development and evaluation of a pharmaceutical care program to reduce modifiable risk of chronic complications in Brazilian type 2 diabetic patients. Lat. Am. J. Pharm., v.30, n. 1, p. 154-160, 2011.

SILVA, G.E.C.; BAZOTTE, R.B. ; CURI, R.; SILVA, M.A.R.C.P. Investigation of risk factors to coronary heart disease in two countryside paranaense villages, Brazil. Braz. Arch. Biol. Technol., v.47, n.3, p.387-390, 2004. 
STRATTON, I.M.; ADLER, A.I.; NEIL, H.A.; MATTHEWS, D.R.; MANLEY, S.E.; CULL, C.A.; HADDEN, D.; TURNER, R.C.; HOLMAN, R.R. Association of glycaemia with macrovascular and microvascular complications of type 2 diabetes (UKPDS 35): prospective observational study. $B M J$, v.321, n.7258, p.405-412, 2000.
UK PROSPECTIVE DIABETES STUDY (UKPDS) GROUP. Intensive blood-glucose control with sulphonylureas or insulin compared with conventional treatment and risk of complications in patients with type 2 diabetes (UKPDS 33). Lancet, v.352, n.9131, p.837-853, 1998.

WILD, S.; ROGLIC, G.; GREEN, A.; SICREE, R.; KING, $\mathrm{H}$. Global prevalence of diabetes: estimates for the year 2000 and projections for 2030. Diabetes Care, v.27, n.5, p.1047-1053, 2004.

Received for publication on $11^{\text {th }}$ August 2010 Accepted for publication on $1^{\text {st }}$ April 2011 
